International Journal of Agriculture, Environment and Bioresearch

Vol. 5, No. 05; 2020

ISSN: $2456-8643$

\title{
ISOLATION, CHARACTERIZATION AND IDENTIFICATION OF BACTERIA ON TWO SELECTED MEDICINAL PLANTS
}

\author{
Akala, A.O., Adegboyega, D.A., Olatunji, A.O., Kolawole, I.O., Edet, S.E, Oloyede, E.O and Akanni, F.O \\ Forestry Research Institute of Nigeria, Ibadan \\ https://doi.org/10.35410/IJAEB.2020.5551
}

\begin{abstract}
Bacterial isolates from Phyllanthus amarus and Azadiractha indica were characterized and identified as a preliminary step in determining an elimination treatment. The 22 bacteria were characterized using biochemical and morphological tests and subjected to sensitivity tests with four antibiotics. The isolates were compared with known organisms and assigned to genera according to similarities in characteristics. Seven isolates were analyzed by fatty acid analysis. Six were classified as Agrobacterium radiobacter; eight as Xanthomonas; one each as Pseudomonas fluorescens, Micrococcus spp., Corynebacterium spp., and Curtobacterium spp.; four could not be assigned to genera. Inhibition of growth of the bacteria by most antibiotics was best at $\mathrm{pH}$ 7.5.Minimal inhibitory concentration and minimal bactericidal concentrations of Gentamicin, Rifampicin, Streptomycin Sulfate, and Timentin varied with genotype.
\end{abstract}

Keywords: Elimination, Isolates, Bactericidal and Inhibitory.

\section{INTRODUCTION}

\section{Phyllanthus amarus}

Phyllanthus amarus is a plant of the family Euphorbiaceae and has about approximately 800 species which are found in tropical and subtropical countries of the world. Traditionally, Phyllanthus amarus herb has found its usefulness in the treatment of several health problems such as diarrhoea, dysentery, dropsy, jaundice, intermittent fevers, urinogenital disorders, scabies and wounds. Topically, it is used for several skin problems ranging from skin ulcers, sores, swelling and itchiness, wounds, bruises, scabies, ulcers and sores, edematous swellings, tubercular ulcers, ringworm, scabby and crusty lesions. Its effect in excretory system is due to its antiurolithic property and it is used in the treatment of kidney/gallstones, other kidney related problems, appendix inflammation and prostate problems ( Khatoon et al., 2004; Sen and Batra, 2013; Ushie et al., 2013). The secondary metabolites present in P. amarus are Alkaloids, Flavonoids, Hydrolysable Tannins (Ellagitannins), Major Lignans, Polyphenols, Riterpenes, Sterols and volatile oil. The main active constituents of P. amarus are Lignans (Phyllanthin, Hypophyllanthin, Nirurin Niranthin, Phyltetralin, Niranthine, Nirtetralin etc. (Morton, 1981; Chevallier, 2000; Srivastava et al., 2008; Kassuya et al., 2006; Huang et al., 2003; Maciel et al., 2007; Singh et al., 2009), Flavonoids (Foo and Wong, 1992; Londhe et al., 2008;), ( Foo, 1995), Triterpenes (phyllanthenol, phyllanthenone, phytllantheol etc.) (Maciel et al., 2007; Foo and Wong, 1992), Alkaloids (Houghton et al., 1996; Kassuya et al., 2006), Sterol (Amarosterol-A, 
Vol. 5, No. $05 ; 2020$

ISSN: $2456-8643$

Amarosterol-B etc.) (Ahmad and Alam , 2003) and volatile oil (Linalool, Phytol etc.) (Moronkola et al., 2009).

Hexane, methanol and water extracts of aerial parts of P.amarus were screened for antimicrobial activities against Bacillus subtilis, Escherichia coli, Pseudomonas aeruginosa, Salmonella typhi, Staphylococcus aureus and Candida albicans using the agar cup diffusion protocol. The aqueous and Methanolic extracts of $P$. amarus were active against all the test microorganisms. In another study, hexane, petroleum ether, chloroform, acetone and methanol extract of Phyllanthus leaves were tested for antibacterial activity against Pseudomonasaeruginosa, Klebsiella pneumonia, Proteus mirabilis, Streptococcus faecalis, Enterobacter species, Serratia marcescens, Staphylococcus aureus and Escherichia coli by agar well diffusion method. The results demonstrated methanol extract of Phyllanthus amarus for highest inhibitory activity against the above bacterial species (Saranraj and Sivasakthivelan, 2012)

The antidiabetic potential of Phyllanthus amarus investigated in an experiment model where fasted rats were made diabetic by single intraperitoneal injection of $120 \mathrm{mg} / \mathrm{kg}$ of Alloxan monohydrates and then two doses of the aqueous and hydroalcoholic extract of Phyllanthus amarus administered orally which were then compared with the normal control group that received distilled water only. After 15 days treatment the result demonstrates aqueous and hydroalcoholic extract of Phyllanthus amarus decrease the blood glucose level significantly. Serum analysis of the treated experimental animals showed an increase in insulin and reduction in the Malondialdehyde concentration, therefore demonstrated the potential antidiabetic property of aqueous and hydroalcoholic extract of Phyllanthus amarus (Evi and Degbeku, 2011).

Iranloye et al (2011), investigated the aqueous leaf extract of $\mathrm{P}$. amarus for analgesic and antiinflammatory activities using both thermal and chemical models of pain assessment in rats. The extract caused a significant $(p<0.05)$ dose related increased inhibition of the carrageenaninduced paw oedema in the rats. The inhibition produced by $200 \mathrm{mg} / \mathrm{kg}$ aqueous extract of $\mathrm{P}$. amarus (70.20\%) was significantly higher than that of the reference drug (acetylsalicylic acid). The extract produced a marked analgesic activity by inhibiting both early and late phases of pain stimulus in formalin induced paw licking rats and also a significant and dose related increase in inhibition of the mean tail immersion duration at varying water bath temperature (50,55 and 60 $\left.{ }^{\circ} \mathrm{C}\right)$.

\section{Azadirachta indica}

Azadirachta indica is a fast growing, evergreen tree found commonly in India, Africa and America. It is a highly esteemed tree with several beneficial properties and applications, especially known for its incredible therapeutic and ethnomedicinal values for mankind. Moreover, it has antiseptic, antifungal, antibacterial, antipyretic, anti-malaria, anti-diabetic and anti-fertility properties among several other uses (Nok et al., 1993, Natarajan et al., 2003; Fredroset al., 2007; Mbaya et al., 2010).Neem elaborates a vast array of biologically active compounds that are chemically diverse and structurally variable with more than 140 compounds isolated from different parts of the tree (Subapriya and Nagini, 2005).

These compounds have been divided into two major classes: isoprenoids and others (Dev kumar and SukhDev, 1996). The Isoprenoids include Diterpenoids and Triterpenoids containing 
Protomeliacins, Limonoids, Azadirone and its derivatives, Gedunin and its derivatives, Vilasinin type of compounds and Csecomeliacins such as Nimbin, Salanin and Azadirachtin. The nonisoprenoids include proteins (amino acids) and carbohydrates (polysaccharides), sulphurous compounds, polyphenolics such as Flavonoids and their glycosides, dihydrochalcone, Coumarin and Tannins, Aliphatic compounds, etc. (Kraus, 1995; Dev kumar and SukhDev, 1996).

The susceptibility of the microorganisms to the extracts of Neem leaves was compared with certain specific antibiotics. The methanol extract of Azadirachta indica exhibited pronounced activity against Bacillus subtilis(Shravan et al., 2011). Neem oil preparations have been found effective against a wide spectrum of bacteria viz., B. cerus, B. pumilus, S. aureus, $M$. tuberculosis, E. coli, P. vulgaris, S. typhi, K. pneumonae, S. dysenterae, Enterococcus faecalis, Streptococcus mutans, Streptococcus salivarius, Streptococcus mitis, Streptococcus sanguis and even Streptomycin resistant strains (Sairam et al.,2000; Prashant et al., 2007; Mehrotra et al., 2010; Sarmiento et al.,2011; Maragathavalli et al., 2012; Vinothkumaret al., 2013; Rosaline et al., 2013). Azadirachta indica leaves possessed good antibacterial activity, confirming the great potential of bioactive compounds and is useful for rationalizing the use of this plant in primary health care (Saradhajyothi and Subbarao, 2011). Studies have also shown that Neem oil has been found to have definite antiplaque activity [Elavarasu et al., 2012]. Neem leaf extract can also inhibit the formation of biofilm in Pseudomonas aeruginosa [Harjaiet al., 2013].

\section{MATERIALS AND METHODS}

\section{Sample Collection and Processing}

Fresh leaves of Phyllantus amarus and Azadirachta indica were collected and identified at the Forestry Research Institute of Nigeria, Oyo State, Nigeria. The leaves were washed properly to remove foreign matter and air dried. The leaves were then grinded to powder with a mechanical grinder, weighed and labeled. The powder was then subjected to various solvent extraction processes.

\section{Source of Test Organisms}

The bacteria were isolated from Crushed leaves of A.indica and P.amarus ,Soaked leaves of $A$. indica and P.amarus, Buried leaves of A.indica and P.amarus. The isolates were subcultured to obtain pure cultures after which they were maintained on nutrient agar slants for further use.

\section{Sterilization of Glassware and Media}

All glassware used in this study were thoroughly washed with detergent, rinsed with water, airdried and sterilized in hot air oven at $160^{\circ} \mathrm{C}$ for two hours. Materials such as mouth of test tube, inoculating loop and inoculating needle were sterilized by flaming with a bunsen burner before and after inoculation to prevent contamination. All media used for isolation, cultivation and identification of isolates were sterilized by autoclaving at $121^{\circ} \mathrm{C}$ for 15 minutes under pressure. 


\section{Identification of Isolates}

Identification of the isolates were done using Gram staining, morphological and biochemical characterisation of bacterial isolates was carried out( Olutiola et al., 2000). The result of each test was recorded and the probable identity of the isolates was deduced with reference to Bergey's manual of Determinative Bacteriology (Bucchanam and Gibbons, 1974)

\section{RESULT AND DISCUSSION}

Table 1: Bacteria Isolates from Phyllantus amarus.

\begin{tabular}{|ll|}
\hline Bacteria Isolates & $\begin{array}{l}\text { Isolate } \\
\text { code }\end{array}$ \\
\hline Staphylococcus sp & $\mathrm{B} 1$ \\
Micrococcus $s p$ & $\mathrm{~B} 2$ \\
Staphylococcus sp & $\mathrm{B} 4$ \\
Staphylococcus sp & $\mathrm{B} 6$ \\
Pseudomonas $s p$ & $\mathrm{~B} 8$ \\
Micrococcus $s p$ & $\mathrm{~B} 9$ \\
Bacillus sp & $\mathrm{S} 1$ \\
Bacillus sp & $\mathrm{S} 2$ \\
Bacillus $s p$ & $\mathrm{~S} 3$ \\
Pseudomonas $s p$ & $\mathrm{~S} 5$ \\
Pseudomonas $s p$ & $\mathrm{~S} 6$ \\
Micrococcus $s p$ & $\mathrm{~S} 8$ \\
Bacillus $s p$ & $\mathrm{G} 1$ \\
Bacillus $s p$ & $\mathrm{G} 2$ \\
Staphylococcus $s p$ & $\mathrm{G} 4$ \\
Corynebacteriumsp & $\mathrm{G} 7$ \\
Corynebacteriumsp & $\mathrm{G} 8$ \\
\hline
\end{tabular}


Pseudomonas $s p$ isolated from the soil and used as control was highly susceptible to both the aqueous and methanol extract of Phyllanthus amarus and also susceptible to the fractions of both extracts

The study also revealed that bacteria that had interacted with Azadirachta indica and Phyllanthus amarus were majorly resistant to the aqueous and methanol extracts of the plants. Also, the bacteria isolated from these plants also proved to be resistant to the ethyl acetate, chloroform and n-hexane fractions of the aqueous and methanol extracts of Azadirachta indica and Phyllanthus amarus, even though the bacteria used as control were all susceptible to the plant extracts at varying concentrations. This could be because the bacteria had developed resistance to the antimicrobials present in these plants during interaction and were no longer susceptible to these antimicrobials.

\section{CONCLUSION}

More than half a century has passed since the first antibiotics were introduced commercially but it did not take long for microbes to develop resistance to these antibiotics with widespread use of many antibacterial drugs providing ideal conditions for the spread of multi drug resistant organisms. Even though research is now focusing on the bioactive phytochemical constituents in medicinal plants as a source and template for the synthesis of new antimicrobial drugs, this study has revealed that bacteria have the tendency to develop resistance to plant antimicrobials after exposure to them. Further studies should be taken to determine the factors involved in the mechanisms of natural antimicrobial/multi-antimicrobial resistance in bacteria and ensure that reverting to the use of plants as new and alternative means of antimicrobial therapy does not eventually become a futile scientific endeavor.

\section{REFERENCES}

Aarestrup, F. M., Seyfarth, A. M., Emborg, H. D., Pedersen, K., Hendriksen, R. S., and

Bager, F. 2001. Effect of abolishment of the use of antimicrobial agents for growth promotion on occurrence of antimicrobial resistance in fecal enterococci from food animals in Denmark. Antimicrob. Agents Chemother. 45: 2054-2059.

Sosa A de J., Byarugaba D.K., Ama' bile-Cuevas C.F., Hsueh P., Kariuki S., OkekeI.N.(2010)(eds.), Antimicrobial Resistance in Developing Countries, DOI 10.1007/978-0387-89370-9_2, Springer Science and Business Media, LLC, 2010. 15.

Ahmad, B., Alam, T., 2003. Components from whole plant of Phyllanthus amarus Linn.

Indian Journal of Chemistry, Section B: Organic Chemistry including Medicinal Chemistry 42, 1786-1790.

Aibinu I E, Ohaegbulam V C, Adenipekun E A, Ogunsola F T, Odugbemi T O, Mee B J. Extended-Spectrum Beta-Lactamase Enzymes in Clinical Isolates of Enterobacter species from Lagos, Nigeria. Journal of Clinical Microbiology. 2003;41(5):2197-2200. 
Aibinu I, Adenipekun E, Odugbemi T. Emergence of Quinolone Resistance amongst Escherichia coli strains isolated from clinical infections in some Lagos State Hospitals in Nigeria. Nigerian Journal of Health and Biomedical Science. 2004;3(2):73-78.

Akerele O (1992) Importance of medicinal plants: WHO's programme. In: Natural Resources and Human Health: plants of medicinal and nutritional value. Elsevier, Amsterdam, Netherlands, 63-77.

Byarugaba, D. K. 2004. A view on antmicrobial resistance in developing countries and responsible risk factors. Int. J. Antimicrob. Agents 24: 105-110.

Byarugaba, D. K. (2005). Antimicrobial resistance and its containment in developing countries.In Antibiotic Policies: Theory and Practice, ed. I. Gould and V. Meer, pp 617-646.

New York: Springer.

Chevallier, A., 2000. Encyclopedia of Herbal Medicine: Natural Health, Second ed. Dorling Kindersley Book, USA, 336 p.

Clinical and Laboratory StandardsInstitute (CLSI) (2011).Performance standards for antimicrobial susceptibilitytesting: Twenty-first Informational Supplement, Vol. 31- No.1PA USA, CLSI: Wayne; M100-21.

Cowan M M. Plant products as antimicrobial agents. Clinical Microbiology Review.

1999;12:564-582.

Dev kumar, C. and SukhDev, in Neem (eds Randhawa and Parmar, B. S.), 1996, 2nd edn, pp.

$77-110$.

Elavarasu, S., P. Abinaya, S. Elanchezhiyan, Thangakumaran, K. Vennila and K.B. Naziya, 2012. Evaluation of anti-plaque microbial activity of Azadirachta indica (neem oil) in vitro:A pilot study. J. Pharm. Bioallied Sci., 4: S394-S396.

Evi PL, Degbeku K. Antidiabetic Activity of Phyllanthusamarus Schum and Thonn on Alloxan induced diabetes inMale Wistar Rats. Journal of Applied Sciences 2011;11(16):2968-2973.

Farnsworth NR, Soejarto DD (1991) Global importance of medicinal plants. In: Conservation of Medicinal Plants. Cambridge University Press, UK 25-52.

Fredros, O.O., K.Y.G. Bart and F. Ulrike, 2007. Larvicidal effects of a neem oil formulation on the malaria vector Anopheles gambiae. MalariaJ., 6: 63-69

Fluit, A. C., Visser, M. R., and Schmitz, F. J. 2001. Molecular detection of antimicrobial resistance. Clin. Microbiol. Rev. 14:836-71.

Foo, L.Y., 1995. Amarinic acid and related ellagitannins from Phyllanthus amarus. Phytochemistry 39, 217-224. 
Foo, L.Y., Wong, H., 1992. Phyllanthusiin D, an unusual hydrolysable tannin from Phyllanthus amarus. Phytochemistry 31, 711-713.

Harjai, K., A. Bala, R.K. Gupta and R. Sharma, 2013. Leaf extract of Azadirachta indica (Neem): A potential antibiofilm agent for Pseudomonas aeruginosa. Pathogens Dis., 69: 62- 65

Hill AF. Economic Botany: A Text Book of Useful Plants and Plant Products. 2nd Edn. New York: McGraw Hill Book Company, Inc.; 1989.

Houghton, P.J., Woldemariama, T.Z., Siobhan, O.S., Thyagarajan, S.P., 1996.Two securinega type alkaloids from Phyllanthus amarus. Phytochemistry 43,715-717.

Huang, R.L., Huang, Y.L., Ou, J.C., Chen, C.C., Hsu, F.L., Chang, C., 2003. Screening of 25 compounds isolated from Phyllanthus Species for anti-human hepatitis B virus in vitro. Phytotherapy Research 17, 449-453.

Iwu, M.W., A.R. Duncan, and C.O. Okunji. 1999.New antimicrobials of Plant Origin. In: J.

Janick,Ed. Perspectives on New Crops and New Uses.

Kassuya, C.A., Silvestre, A., Menezes-de-Lima Jr., O., Marotta, D.M., Rehder, V.L. Calixto,

J.B., 2006. Antiinflammatory and antiallodynic actions of the lignin niranthin isolated from Phyllanthus amarus. Evidence for interaction withplatelet activating factor receptor, European Journal of Pharmacology 546,182-188.

Knobloch K, Pauli A, Iberl B. Antibacterial and antifungal properties of essential oil components. J Essent Oil Res. 1989;1(3):119-28.

Komolafe OO (2003). Antibiotic resistance in bacteria - an emerging public health problem.

Malawi Med. J. 15:63-67.

Khatoon S, Rai V, Rawat A. Comparative pharmacognostic studies of three Phyllanthus species. Journal of Ethnopharmacology 2004; 104:79-86.

Kraus, W., in The Neem Tree: Source of Unique Natural Products for Integrated Pest Management, Medicine, Industry and Other Purposes (ed. Schmutterer, H.), 1995, pp 35-88.

Lewis K, Ausubel FM (2006). Prospects for plant-derived antibacterials. Nat. Biotechnol. 24(12): 1504-1507.

Levy, S.B. and R.V. Miller (eds.) (1989) Gene Transfer in the Environment. McGraw Hill, New York. 
Vol. 5, No. 05; 2020

ISSN: $2456-8643$

Levy SB (2002). The antibioticparadox: How the Misuse ofantibiotics destroys their curative powers. Cambridge, MA: PerseusPublishing.

Londhe, J.S., Devasagayam, T.P., Foo, L.Y., Ghaskadbi, S.S., 2008. Antioxidant activity of some polyphenol constituents of the medicinal plant Phyllanthus amarus Linn.Redox Report 13, 199-207.

Maciel, M.A.M., Cunha, A., Dantas, F.T.N.C., Kaiser, C.R., 2007. NMR characterization of bioactive lignans from Phyllanthus amarus Schum \& Thonn. Journal of Magnetic Resonance Imaging 6, 76-82.

Mahady, G.B. 2005. Medicinal plants for theprevention and treatment of bacterial infections Curr. Pharm. Des. 11:2405-2427.

Maragathavalli, S., S. Brindha, N.S. Kaviyarasi, B. Annadurai and S.K. Gangwar, 2012. Antimicrobial activity in leaf extract of Neem (Azadirachta indica Linn.). Int. J. Sci. Nat., 3: 110113

Mbaya, W.A., U.I. Ibrahim, O. Thank God and L. Sanya, 2010. Toxicityand potential anti-

trypanosomal activity of ethanolic extract ofAzadirachta indica (Maliacea) stem bark: an in

vivo and in vitroapproach using Trypanosoma brucei. J. Ethnopharm., 128: 495-500

Medina, A.L., M.E. Lucero, F.O. Holguin, R.E.Estell, J.F Posakony, J. Simon, and M. O'Connell. 2005. Composition and antimicrobialactivity of Anemopsis californica leaf oil. J. Agri.Food Chem. 53:8694-8698.

Mehrotra, S., A.K. Srivastava and S.P. Nandi, 2010. Comparative antimicrobial activities of Neem, Amla, Aloe, Assam tea and Clove extracts against Vibrio cholerae, Staphylococcus aureus and Pseudomonas aeruginosa. J. Med. Plants Res., 4: 2473-2478.

Moreillion P, Que YA, Glauser MP. Staphylococcus aureus (Including Staphyloccal Toxic shock) In: Mandell GL, Bennett JE, Dolin R, editors. 'Principles and Practice of Infectious diseases'. 6th ed. Vol. 2. Pennyslyvania: Published by Churchill livingstone; 2005. pp. 23332339 .

Moronkola, D.O., Ogunwande, I.A., Oyewole, I.O., Baser, K.H.C., Ozek, T., Ozek, G., 2009. Studies on the volatile oils of Momordica charantia L. (Cucurbitaceae) and Phyllanthus amarus Sch.et Thonn (Euphorbiaceae). Journal of Essential Oil Research 21, 393-399

Morton, J.F., 1981. Atlas of Medicinal Plants of Middle America. Library of Congress Cataloging in Publication Data. Thomas books, 1420 p.

Natarajan, V., V.P. Venugopal and T. Menon, 2003. Effect of Azadirachta Indica on the growth pattern of dermatophytes. Ind. J. Med.Microbiol., 21: 98-101 
Vol. 5, No. 05; 2020

ISSN: $2456-8643$

Nok, A.J., E. Kan, I. Hongdet, S. Arowosafe, C.P. Onyenekwe , E.C. Gimbaand A.J. Kagbu, 1993. Trypanocodal Potentials of Azadichracta indica: In vivo activity of leaf extract against T.b. brucei. J. Clin.Biochem. Nutr., 15: 113-118

Obianime A.W and Uche, F.I. (2009) The Phytochemical constituents and the effects of methanol extracts of Phyllanthus amarus leaves (kidney stone plant) on the hormonal parameters of Male guinea pigs.J. Appl. Sci. Environ. Management.Vol. 13(1) 5- 9

Olayinka AA, Anthony JA,Anthony OI (2009). Synergisticinteraction of Helichrysum pedunculatum leaf extracts withantibiotics against wound infectionassociated bacteria. Biologicalresearch., 42: 327-338.

Padulosi S, Leaman D, Quek P (2002) Challenges and opportunities in enhancing the conservation and use of medicinal and aromatic plants. J Herbs Spices Med Plants 9: 243-267.

Prashant, G.M., G.N. Chandu, K.S. Murulikrishna and M.D. Shafiulla, 2007. The effect of mango and Neem extract on four organisms causing dental caries: Streptococcus mutans, Streptococcus salivarius, Streptococcus mitis and Streptococcus sanguis: An in vitro study. Indian J. Dent. Res., 18: 148-151.

Prescott LM, Harley JP, Klein DA, 2002. Microbiology, 5th Edition, McGraw-Hill, New York. 1014pp.

Pretorius JC, Magama S, Zietsman PC. Growth inhibition of plant pathogenic bacteria and fungi by extracts from selected South African plant species. South African Journal of Botany. 2003;20:188-192.

Romero, C,D., S.E. Choph, G. Buck, E. Martinez, M.Garcia, and L. Bixby. 2005. Antibacterial properties of common herbal remedies of thesouthwest. J. Ethnopharmacol. 99:253-257.

Rosaline, H., D. Kandaswamy, D. Gogulnath and M. Rubin, 2013. Influence of various herbal irrigants as a final rinse on the adherence ofEnterococcus faecalis by fluorescence confocal laser scanning microscope. J. Conserv. Dent., 16: 352-355.

SaiRam, M., G. Ilavazhagan, S.K. Sharma, S.A. Dhanraj and B. Suresh et al., 2000. Anti-

microbial activity of a new vaginal contraceptive NIM-76 from Neem oil (Azadirachta indica). J. Ethnophamacol., 71: 377-382.

Saradhajyothi Koona, Subbarao Budida (2011) Antimicrobial potential of the extracts of the leave of Azadirachta indica, Linn. Nat Sci Biol, 3(1) 65-69.

Sarmiento, W.C., C.C. Maramba and M.L.M. Gonzales, 2011. An in-vitro study on the antibacterial effect of Neem (Azadirachta indica) leaf extract on methicillin-sensitive and 
Methicillin-resistant Staphylococcus aureus. PIDSP J., 12: 40-45.Sen A, Batra A. The study of in vitro and in vivoantioxidant activity and total phenolic content of Phyllanthus amarus Schum Thonn: A medicinally importantplant. International Journal of Pharmacy and PharmaceuticalSciences 2013; 5:947.

Shravan K.D., Ramakrishna R., Santhosh K.M., Kannappan N.,In vivo Antidiabetic evaluation of Neem leaf extract in alloxan induced rats, Journal of Applied Pharmaceutical Science.,1(4), 100-105 (2011)

Sibanda, T. and A.I. Okoh. 2007. The challenges ofovercoming antibiotic resistance; Plant extracts aspotential sources of antimicrobial and resistancemodifying agents. Afr, J. Biotechnol. 6:2886-2896.

Singh, M., Tiwari, N., Shanker, K., Verma, R.K., Gupta, A.K., Gupta, M.M., 2009. Two new lignans from Phyllanthus amarus. Journal of Asian Natural Products Research 11, 562-568. Sofowora A. Medicinal Plants and Traditional Medicinal in Africa. New York: John Wiley and Sons; 1982.

Srivastava, V., Singh, M., Malasoni, R., Shanker, K., Verma, R.K., Gupta, M.M., Gupta, A.K., Khanuja, S.P.S., 2008. Separation and quantification of lignans in Phyllanthus species by a simple chiral densitometric method. Journal of Separation Science 31, 2338.

Stefanovic, O., Stanojevic, D. \& Comic, Lj. (2012). Synergistic antibacterial activity of Salvia officinalis and Cichorium intybus extracts and antibiotics. Acta Poloniae Pharmaceutica - Drug Research, Vol. 3, ISSN 0001-6837 (in press)

Stuart B and Bonnie M (2004).Antibacterial resistance worldwide:causes, challenges and responses.Nature Medicine., 10: 122-129.

Subapriya. R. and Nagini. S, 2005. Medicinal properties of neem leaves: areview. Curr. Med. Chem. Anticancer Agents, 5: 149-160

Usha PTA., Jose S., Nisha AR(2010). Antimicrobial drugresistance-a global concern. Veterinary World., 3: 138-139.

Ushie O, Neji P, Etim E. Phytochemical screening andantimicrobial activities of Phyllanthus amarus stem barkextracts. International Journal of Modern Biology and Medicines 2013; 3:101-112.

Vinothkumar, T.S., M.I. Rubin, L. Balaji and D. Kandaswamy, 2013. In vitro evaluation of five different herbal extracts as an antimicrobial endodontic irrigant using real time quantitative polymerase chain reaction. J. Conserv. Dent., 16: 167-170.

Walsh, C. 2000. Molecular mechanisms that confer antibacterial drug resistance. Nature 406:

$775-781$

Williams R. Antimicrobial resistance a global threat. Essential Drug Monitor. 2000;28-29:1. 
International Journal of Agriculture, Environment and Bioresearch

Vol. 5, No. 05; 2020

ISSN: $2456-8643$

World Health Organization (WHO), author Traditional medicine. Fact sheet number 134.

Revised May, 2003. 2001. Available on http/www.who.int/mediacentrefactsheet/fs/134

Zhu, L., Lin, J., Ma, J., Cronan, J. E. \& Wang, H. Triclosan resistance of Pseudomonas aeruginosa $\mathrm{PAO} 1$ is due to $\mathrm{FabV}$, a triclosan-resistant enoyl-acyl carrier protein reductase.

Antimicrob. Agents Chemother. 54, 689-698 (2010). 